\title{
Metallic materials for 3D printing
}

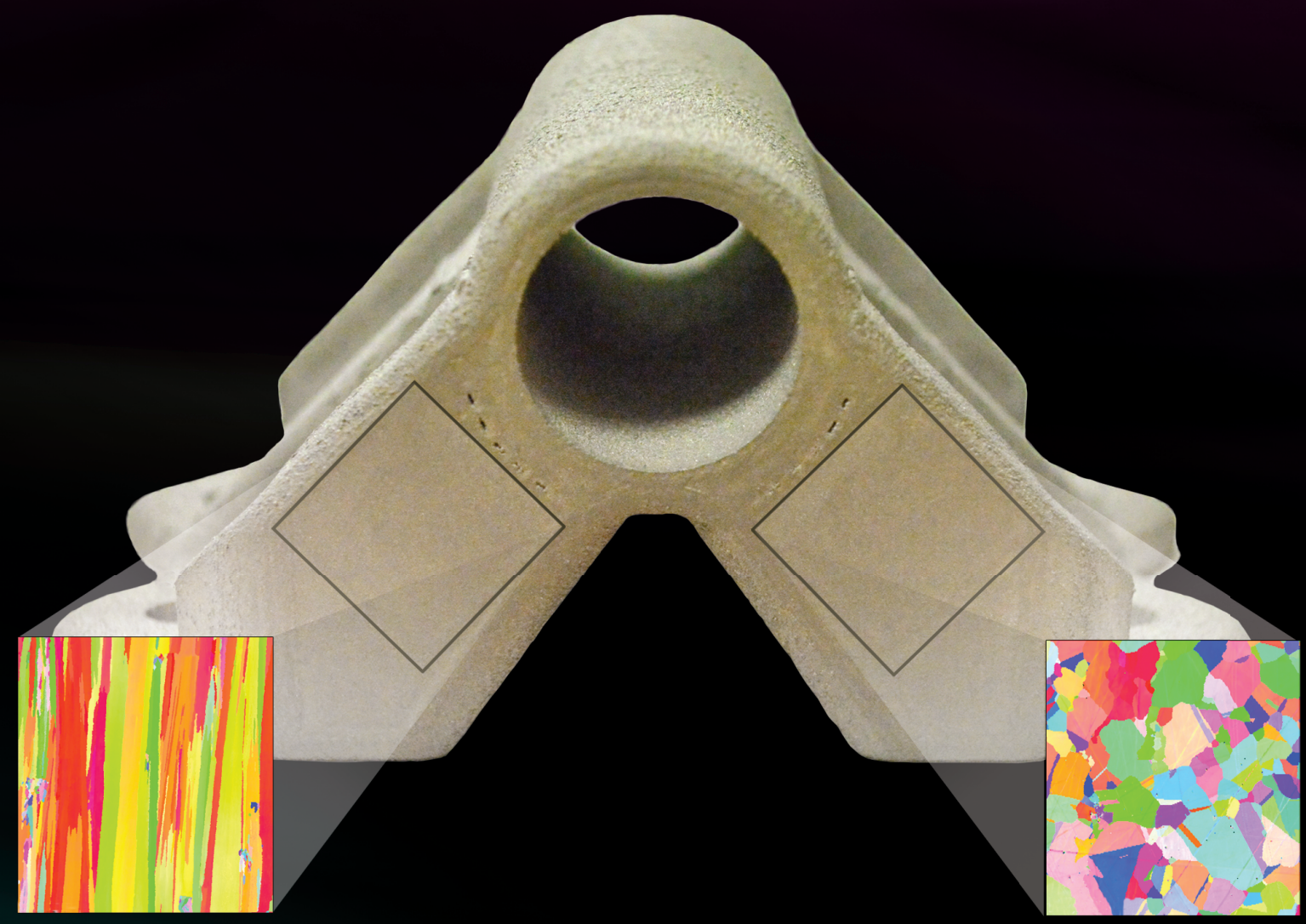

\section{ALSO IN THIS ISSUE}

Synthesis and applications of conducting polymer nanofibers

TEM of specimens and processes in liquids 


\section{CUSTOMIZED PRODUCTION ION IMPLANTERS}

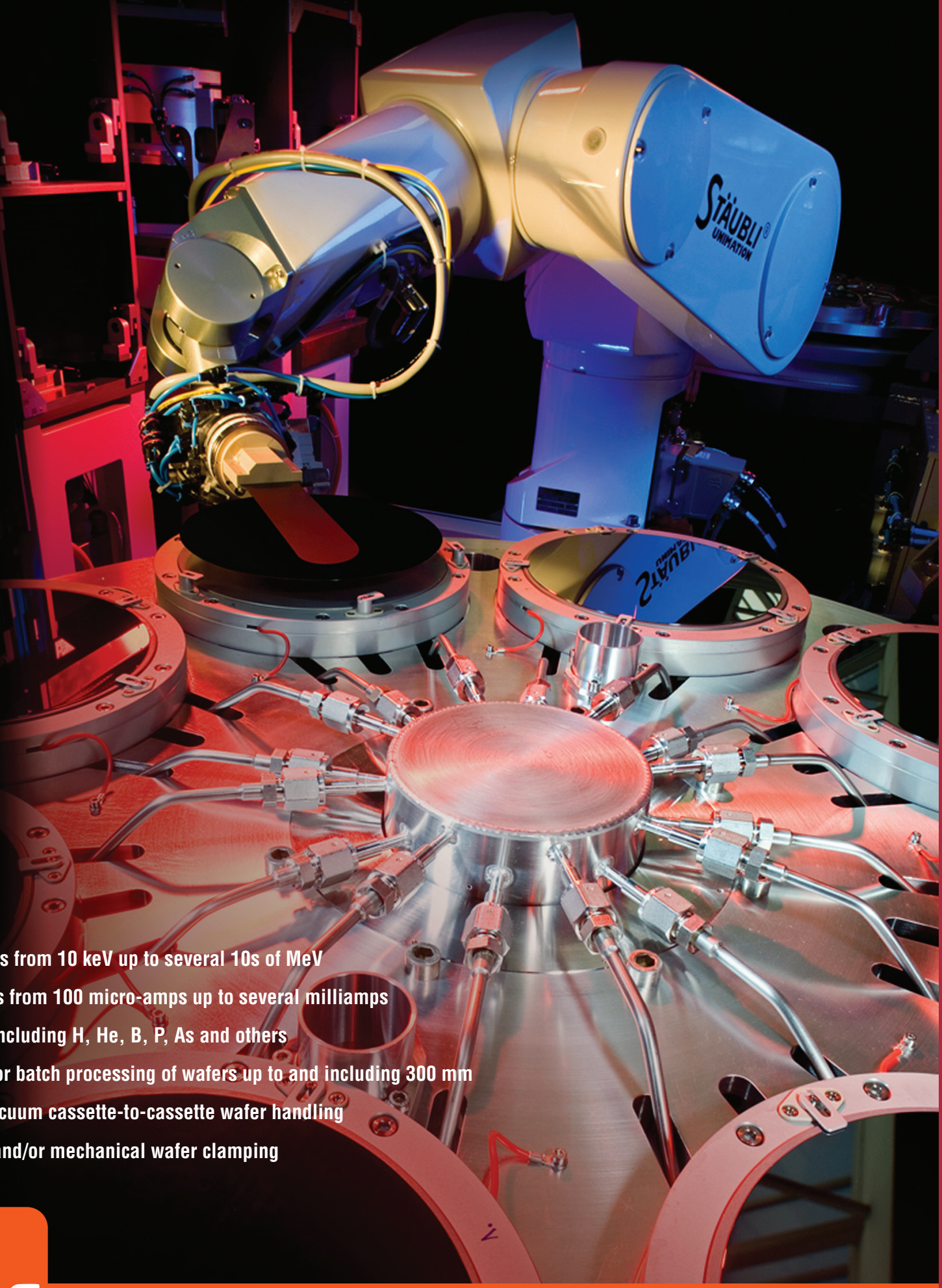

Beam energies from $10 \mathrm{keV}$ up to several $10 \mathrm{~s}$ of $\mathrm{Me}$

Beam currents from 100 micro-amps up to several milliamps

- Ion species, including $\mathrm{H}, \mathrm{He}, \mathrm{B}, \mathrm{P}, \mathrm{As}$ and others

Single wafer or batch processing of wafers up to and including $300 \mathrm{~mm}$

- In-air or in-vacuum cassette-to-cassette wafer handling

- Electrostatic and/or mechanical wafer clamping

\section{Hr High Voltage Engineering}

High Voltage Engineering Europa B.V.

P.O. Box 99, 3800 AB Amersfoort, The Netherlands

Tel: $31334619741 \cdot$ info@highvolteng.com

www.highvolteng.com 

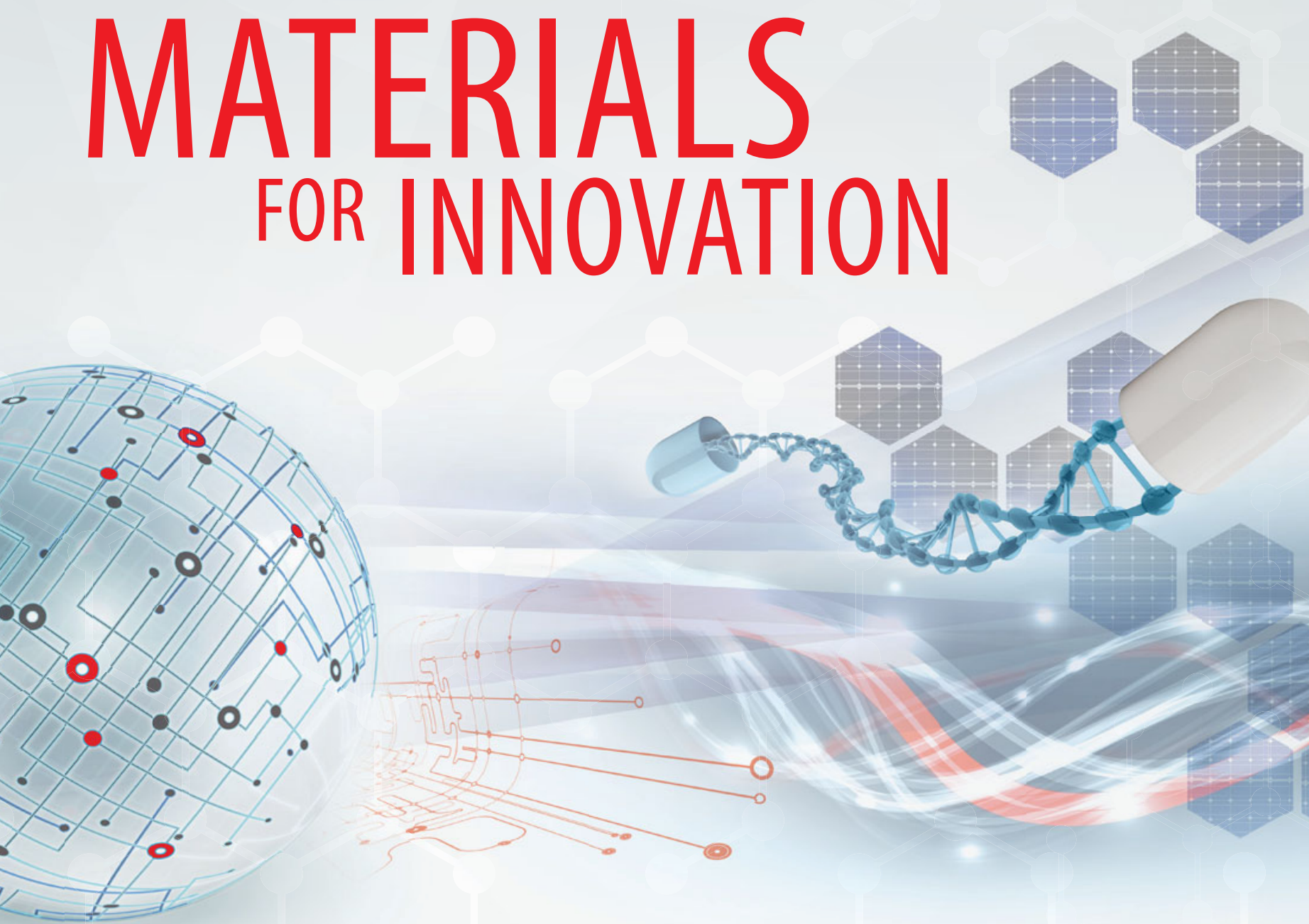

\section{ENERGY}

\section{BIOMEDICAL}

Materials for drug delivery, tissue engineering, and regenerative medicine; PEGs, biodegradable and natural polymers; functionalized nanoparticles; block copolymers, dendrimers and nanoclays

\section{ELECTRONICS}

Nanowires; printed electronics inks and pastes; materials for OPV, OFET, OLED nanodispersions; CNTs and graphene; precursors for PVD, CVD, and sputtering
Ready-to-use battery grade electrode and electrolyte materials; nanopowders, nanostructures and dispersions; quantum dots; perovskites; fuel cells and membrane; hydrogen storage materials including MOFs; phosphors; thermoelectrics; high purity salts

Find more information on our capabilities at aldrich.com/matsci 


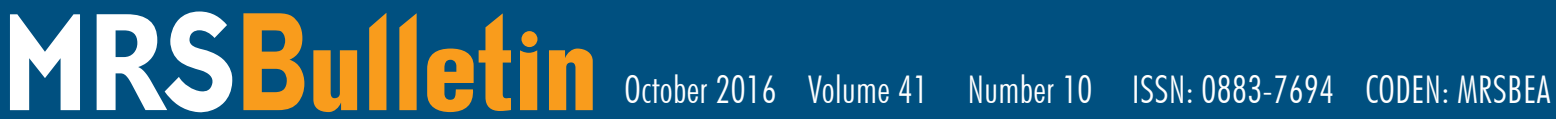
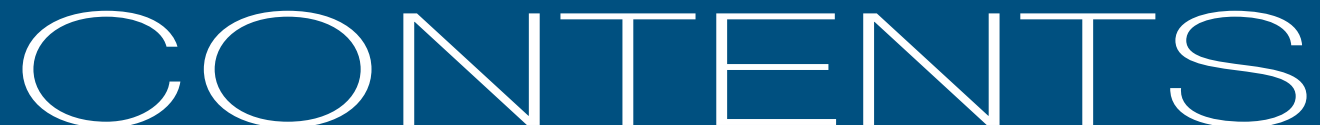

\section{METALLIC MATERIALS FOR 3D PRINTING}

729 Metallic materials for 3D printing

Suman Das, David L. Bourell, and S.S. Babu,

Guest Editors

\section{Meet Our Authors}

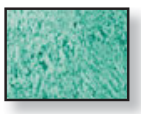

745 Microstructure and mechanical property considerations in additive manufacturing of aluminum alloys

Y. Ding, J.A. Muñiz-Lerma, M. Trask, S. Chou, A. Walker, and M. Brochu

752 Electron-beam additive manufacturing of high-temperature metals

Lawrence E. Murr and Shujun Li

758 Additive manufacturing of Ni-based superalloys: The outstanding issues Moataz M. Attallah, Rachel Jennings, Xiqian Wang, and Luke N. Carter

765 Laser additive manufacturing of bulk and porous shape-memory NiTi alloys: From processes to potential biomedical applications

Sasan Dadbakhsh, Mathew Speirs, Jan Van Humbeeck, and Jean-Pierre Kruth

775 Additive manufacturing and postprocessing of Ti-6Al-4V for superior mechanical properties M. Qian, W. Xu, M. Brandt, and H.P. Tang

\section{TECHNICAL FEATURES}

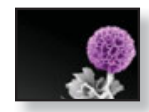

785 Synthesis and applications of conducting polymer nanofibers MRS Medal presentation 2015 MRS Fall Meeting

Richard B. Kaner

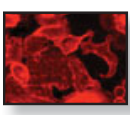

791 Transmission electron microscopy of specimens and processes in liquids Innovation in Materials Characterization Award presentation 2016 MRS Spring Meeting Frances M. Ross, Chongmin Wang, and Niels de Jonge

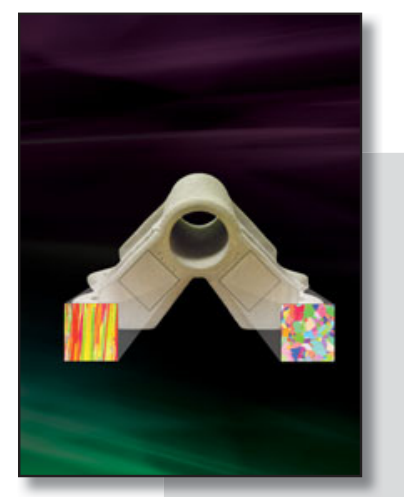

\section{ON THE COVER}

Metallic materials for 3D printing Three-dimensional (3D) printing of metallic materials involves the consolidation of feedstock materials in the form of powder. wire, or sheet using various energy sources to form complex shapes. The past two decades have seen significant advances in the field in terms of both materials and technologies for metal $3 \mathrm{D}$ printing. The cover shows an additively manufactured nickel-based superalloy component, which was 3D-printed at Oak Ridge National Laboratory, demonstrating the ability to print on-demand metallic microstructures to target tailored properties. The component is a bracket meant for aerospace use. The two insets are electron backscatter images depicting the difference in texture between the two regions. The one on the left is a columnar grained material, and the one on the right is an equiaxed microstructure. See the technical theme that begins on page 729 . 


\section{DEPARTMENTS}

\section{NEWS \& ANALYSIS}

\section{Materials News}

- LIGO optical coatings pose new challenges in materials research Rachel Berkowitz

- Researchers take diamond defect to new depths in magnetic imaging Omar Fabian

- Kirigami honeycomb material exhibits a "Poisson's switch" Vineet Venugopal

- Electric fields help oxygen slip through the cracks for ultralow power electronics Ian McDonald

- Novel method developed to investigate stiffness and mechanical stress in Li-ion batteries Boris Dyatkin

\section{Science Policy}

- Latest roadmap of EU's European Strategy Forum continues to fund materials research Angela Saini

- US-India partnership announces USD\$30 million expansion to advance clean energy research

\section{FEATURES}

\section{Books}

- Organic Electro-Optics and Photonics: Molecules, Polymers, and Crystals Larry R. Dalton, Peter Günter, Mojca Jazbinsek, 0-Pil Kwon, and Philip A. Sullivan Reviewed by Thomas M. Cooper

- Nanomaterials in Extreme Environments: Fundamentals and Applications Rostislav A. Andrievski and Arsen V. Khatchoyan Reviewed by Ram Devanathan

- Flexible Electronics: From Materials to Devices Guozhen Shen and Zhiyong Fan, Editors Reviewed by Jianguo Lu

824 Image Gallery

Look Again

\section{SOCIETY NEWS}

804 - Team-taught course simultaneously impacts the improvement of science and social literacy

- Preview: 2016 Materials Research Society Fall Meeting \& Exhibit

- Charles M. Lieber to receive 2016 Von Hippel Award for research on nanoscale wires

- James De Yoreo selected for 2016 David Turnbull Lectureship Award

- Gerbrand Ceder receives 2016 Materials Theory Award

- Robert J. Cava selected as MRS Medalist for work on 3D topological insulators

- Andrea Alù to present Kavli Foundation Early Career Lectureship in Materials Science

- Ellen D. Williams to present the Fred Kavli Distinguished Lectureship in Materials Science address

\section{CAREER CENTRAL}

\section{ADVERTISERS IN THIS ISSUE}

Aldrich Materials Science

American Elements

Lake Shore Cryotronics, Inc.

High Voltage Engineering

Hysitron, Inc.

National Electrostatics Corp.

Rigaku Corporation
Page No. . .713 Outside back cover Inside back cover . Inside front cover .728 741 .75 www.mrs.org/bulletin

www.mrs.org/energy-quarterly

www.mrs.org/mymrs

http://journals.cambridge.org

mrsbulletin-rss

@mrsbulletin 


\section{$\mathrm{M}|\mathrm{R}| \mathrm{S}$}

MATERIALS RESEARCH SOCIETY ${ }^{\circledR}$

Advancing materials. Improving the quality of life.
EDITORIAL OFFICE 506 Keystone Drive, Warrendale, PA 15086-7573 USA Bulletin@mrs.org tel 724.779.2747 fax 724.779.8313 www.mrs.org

\section{About the Materials Research Society}

The Materials Research Society (MRS), a not-for-profit scientific association founded in 1973 and headquartered in Warrendale, Pennsylvania, USA, promotes interdisciplinary materials research. Today, MRS is a growing, vibrant, member-driven organization of over 16,000 materials researchers spanning over 80 countries, from academia, industry, and government, and a recognized leader in the advancement of interdisciplinary materials research.

The Society's interdisciplinary approach differs from that of single-discipline professional societies because it promotes information exchange across many scientific and technical fields touching materials development. MRS conducts three major international annual meetings and also sponsors numerous single-topic scientific meetings. The Society recognizes professional and technical excellence and fosters technical interaction through University Chapters. In the international arena, MRS implements bilateral projects with partner organizations to benefit the worldwide materials community. The Materials Research Society Foundation helps the Society advance its mission by supporting various projects and initiatives.

\section{MRS BOARD OF DIRECTORS}

President Kristi S. Anseth, University of Colorado Boulder, USA Immediate Past President Oliver Kraft, Karlsruhe Institute of Technology, Germany Vice President and President-Elect Susan Trolier-McKinstry, The Pennsylvania State University, USA

Secretary Sean J. Hearne, Sandia National Laboratories, USA Treasurer David J. Parrillo, The Dow Chemical Company, USA Executive Director Todd M. Osman, Materials Research Society, USA

Charles T. Black, Brookhaven National Laboratory, USA Alexandra Boltasseva, Purdue University, USA C. Jeffrey Brinker, Sandia National Laboratories and The University of New Mexico, USA

Matthew Copel, IBM TJ Watson Research Center, USA Paul S. Drzaic, Apple, Inc., USA Yury Gogotsi, Drexel University, USA

Hideo Hosono, Tokyo Institute of Technology, Japan Young-Chang Joo, Seoul National University, South Korea Karen L. Kavanagh, Simon Fraser University, Canada

Kornelius Nielsch, Leibniz Institute for Solid State and Materials Research, Germany Christine Ortiz, Massachusetts Institute of Technology, USA

Sabrina Sartori, University of Oslo, Norway

Magaly Spector, The University of Texas at Dallas, USA

Loucas Tsakalakos, GE Global Research, USA

Anke Weidenkaff, University of Stuttgart, Germany

\section{MRS OPERATING COMMITTEE CHAIRS}

Academic Affairs Bruce M. Clemens, Stanford University, USA

Awards Albert Polman, FOM Institute AMOLF, The Netherlands

Government Affairs Kevin Whittlesey, CA Institute for Regenerative Medicine, USA

Meetings David S. Ginley, National Renewable Energy Laboratory, USA

Member Engagement Yves J. Chabal, The University of Texas at Dallas, USA

Public Outreach Elizabeth Kupp, The Pennsylvania State University, USA

Publications Richard A. Vaia, US Air Force Research Laboratory

\section{MRS HEADQUARTERS}

Todd M. Osman, Executive Director

J. Ardie Dillen, Director of Finance and Administration

Damon Dozier, Director of Government Affairs

Patricia Hastings, Director of Meetings Activities

Eileen M. Kiley, Director of Communications
Editor

Gopal R. Rao, rao@mrs.org

Managing Editor

Lori A. Wilson, Iwilson@mrs.org

News Editor

Judy Meiksin, meiksin@mrs.org

Technical Editor

Lisa C. Oldham, oldham@mrs.org

Editorial Assistants

Michelle S. Raley, raley@mrs.org

Mary Wilmoth

Associate Technical Editor

Tobias Lockwood

Production/Design

Andrea Pekelnicky-Frye, Felicia Turano,

Rebecca Yokum, and TNQ

Associate Production Editor

Niki Rokicki

Principal Development Editor

Elizabeth L. Fleischer

Director of Communications

Eileen M. Kiley
Guest Editors

Suman Das, David L. Bourell, and S.S. Babu

Special Consultant

Angelika Veziridis

Energy Quarterly

George Crabtree (Co-Chair)

Elizabeth A. Kócs (Co-Chair)

Andrea Ambrosini, Monika Backhaus,

David Cahen, Russell R. Chianelli,

Shirley Meng, Sabrina Sartori, Anke

Weidenkaff, M. Stanley Whittingham, and Steve M. Yalisove

Advertising/Sponsorship

Mary E. Kaufold, kaufold@mrs.org

Donna L. Watterson, watterson@mrs.org

Member Subscriptions

Michelle Judt, judt@mrs.org

Non-Member Subscriptions

subscriptions_newyork@cambridge.org

\section{EDITORIAL BOARD}

Fiona C. Meldrum (Chair), University of Leeds, UK

V.S. Arunachalam, Center for Study of Science, Technology \& Policy, India

Christopher Bettinger, Carnegie Mellon University, USA

Paul S. Drzaic, Apple, Inc., USA

Igor Lubomirsky, Weizmann Institute, Israe

Amit Misra, University of Michigan, USA

Steven C. Moss, The Aerospace Corporation, USA

Julie A. Nucci, Cornell University, USA

Linda J. Olafsen, Baylor University, USA

James W. Stasiak, HP Inc., USA

Carol Trager-Cowan, University of Strathclyde, UK

Anke Weidenkaff, University of Stuttgart, Germany

Eric Werwa, Washington, DC, USA

M. Stanley Whittingham, Binghamton University, The State University of New York, USA

Steve M. Yalisove, University of Michigan, USA

\section{VOLUME ORGANIZERS}

2016 Ilke Arslan, Pacific Northwest National Laboratory, USA

Rick Barto, Lockheed Martin Advanced Technology Laboratories, USA

Boaz Pokroy, Technion-Israel Institute of Technology, Israel

Zhiwei Shan, Xi'an Jiaotong University, China

2017 Ken Haenen, Hasselt University \& IMEC vzw, Belgium John C. Mauro, Corning Incorporated, USA

Michael S. Strano, Massachusetts Institute of Technology, USA

Joyce Y. Wong, Boston University, USA

2018 Karsten Albe, Technische Universität Darmstadt, Germany Hiroshi Funakubo, Tokyo Institute of Technology, Japan Michael Hickner, The Pennsylvania State University, USA Bethanie Stadler, University of Minnesota, USA

MRS Bulletin (ISSN: 0883-7694, print; ISSN 1938-1425, online) is published monthly by the Materials Research Society, 506 Keystone Drive, Warrendale, PA 15086-7573. Copyright @ 2016 Materials Research Society. Permission required to reproduce content. Periodical postage paid at New York, NY, and at additional mailing offices. POSTMASTER: Send address changes to MRS Bulletin in care of the Journals Department, Cambridge University Press, 100 Brook Hill Drive, West Nyack, NY 10994-2113, USA. Printed in the U.S.A.

Membership in MRS is $\$ 125$ annually for regular members, $\$ 30$ for students. Dues include an allocation of $\$ 29$ for a subscription to MRS Bulletin. Individual member subscriptions ar for personal use only. Non-member subscription rates are $\$ 483$ for one calendar year (12 issues) within North America and $\$ 580$ elsewhere. Requests from subscribers for missing journal issues will be honored without charge only if received within six months of the issue's actual date of publication.

MRS Bulletin is included in Current Contents $\odot /$ Engineering, Computing, and Technology; Current Contents $\circledast /$ Physical, Chemical, and Earth Sciences, the SciSearch ${ }^{\circledast}$ online database, Research Alert ${ }^{\oplus}$, Science Citation Index ${ }^{\oplus}$, and the Materials Science Citation Index ${ }^{\top M}$. Back volumes of MRS Bulletin are available on microfiche through University Microfilms Inc., 300 North Zeeb Road, Ann Arbor, MI 48106, USA.

Authors of each technical article appearing in MRS Bulletin are solely responsible for all content in their article(s), including accuracy of the facts, statements, and citing resources. Facts and opinions are solely the personal statements of the respective authors and do not necessarily represent the views of the editors, the Materials Research Society, or Cambridge University Press.

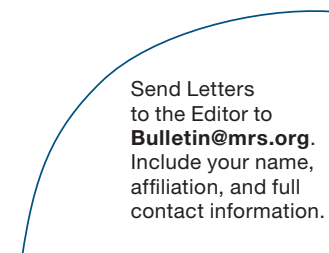




\section{$2016 \mathrm{M}|\mathrm{R}| \mathrm{S}{ }^{\oplus}$ FALL MEETING \& EXHIBIT}

November 27 - December 2, 2016 | Boston, Massachusetts

\section{MRS FALL MEETING SYMPOSIA}

\section{Register by November 11 and SAVE!}

\section{BROADER IMPACT}

BI1 Today's Teaching and Learning in Materials ScienceChallenges and Advances

BI2 The Business of Materials Technology

\section{BIOMATERIALS AND SOFT MATERIALS}

BM1 Spatiotemporally and Morphologically-Controlled Biomaterials for Medical Applications

BM2 Stimuli Responsive Organic and Inorganic Nanomaterials for Biomedical Applications and Biosafety

BM3 Biomaterials for Regenerative Medicine

BM4 Materials and Manufacturing of Biointerfaces Devices and Stretchable Electronics

BM5 Materials for Biointegrated Photonic Systems

BM6 Fabrication, Characterization and Applications of Bioinspired Nanostructured Materials

BM7 Functional Nanostructured Polymers for Emerging Energy Technologies

\section{ELECTROCHEMISTRY}

EC1 Redox Activity on the Molecular LevelFundamental Studies and Applications

EC2 Facilitating Charge Transport in Electrochemical Energy Storage Materials

EC3 Catalytic Materials for Energy and Sustainability

EC4 Material, Devices and Systems for Sustainable Conversion of Solar Energy to Fuels

EC5 Proton Transfer and Transport-

From Biological Systems to Energy Applications

\section{www.mrs.org/fall2016}

\section{Meeting Chairs}

Bernard Bewlay, GE Global Research

Silvija Gradečak, Massachusetts Institute of Technology Sarah Heilshorn, Stanford University

Ralph Spolenak, ETH Zürich

T. Venky Venkatesan, National University of Singapore

Don't Miss These Future MRS Meetings!

2017 MRS Spring Meeting \& Exhibit

April $17-21,2017$

Phoenix, Arizona

2017 MRS Fall Meeting \& Exhibit November 26 - December 1, 2017

Boston, Massachusetts

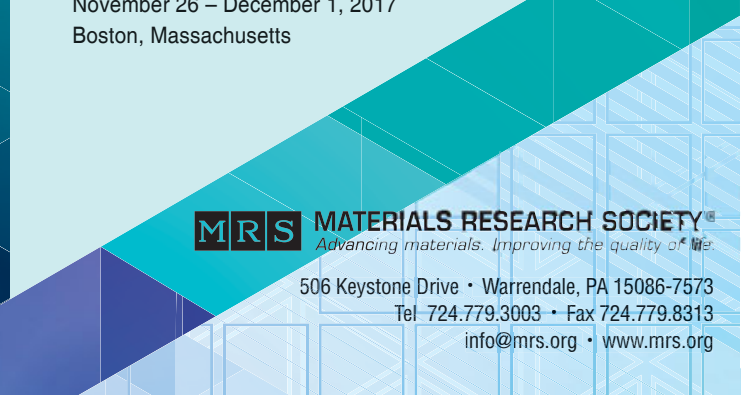

\section{ELECTRONICS, MAGNETICS AND PHOTONICS}

EM1 Materials Issues for Quantum Computing

EM2 Rare-Earths in Advanced Photonics and Spintronics

EM3 Electronic and Ionic Dynamics at Solid-Liquid Interfaces

EM4 Structure-Property Relationships of Organic Semiconductors

EM5 Materials and Mechanisms of Correlated Electronic Phenomena in Oxide Heterostructures

EM6 Thin-Film Transistors-New Materials and Device Concepts

EM7 Functional Plasmonics

EM8 Spin Dynamics in Nonmagnetic Materials and Devices

EM9 Materials and Nanostructures for Magnetic Skyrmions

EM10 Emerging Materials and Technologies for Nonvolatile Memories

EM11 Wide-Bandgap Materials for Energy Efficiency-

Power Electronics and Solid-State Lighting

EM12 Diamond Electronics, Sensors and Biotechnology_Fundamentals to Applications

\section{ENERGY AND SUSTAINABILITY}

ES1 Materials Science and Chemistry for Grid-Scale Energy Storage

ES2 Materials Challenges for Flow-Based Energy Conversion and Storage

ES3 Perovskite Solar Cell Research from Material Properties to Photovoltaic Function

ES4 Thermoelectric Polymers and CompositesNontraditional Routes to High Efficiency

ES5 Materials Research and Design for A Nuclear Renaissance

ES6 Scientific Basis for Nuclear Waste Management

\section{MECHANICAL BEHAVIOR AND FAILURE MECHANISIMS OF MATERIALS}

MB1 Intermetallic-Based Alloys-From Fundamentals to Applications

MB2 Materials under Mechanical Extremes

MB3 High-Entropy Alloys

MB4 Glassy, Nanocrystalline and Other Complex Alloy Systems and Their Applications

MB5 Size Effects and Small-Scale Mechanical Behavior of Materials

MB6 Cyclic Deformation and Fracture at the Nanoscale

MB7 Shear Transformation Mechanisms and Their Effect on Mechanical Behavior of Crystalline Materials

\section{NANOMATERIALS}

NM1 Semiconducting Nanowires, Nanoribbons and HeterostructuresSynthesis, Characterizations and Functional Devices

NM2 2D Layers and Heterostructures beyond GrapheneTheory, Preparation, Properties and Devices

NM3 Nanotubes and Related Nanostructures

NM4 Nanomaterials-Based Solar Energy Conversion

NM5 Nanomembrane Materials-From Fabrication to Application

NM6 Nanoscale Materials and Devices by High-Temperature Gas-Phase Processes

\section{PROCESSING AND MANUFACTURING}

PM1 Ion Beam-Enabled Nanoscale Fabrication, Modification and Synthesis PM2 Plasma Processing via Liquid for Life Sciences and Environmental Applications PM3 Science-Enabled Advances in Materials- and Manufacturing-Technologies PM4 Novel Materials, Fabrication Routes and Devices for Environmental Monitoring PM5 Hierarchical, Hybrid and Roll-to-Roll Manufacturing for Device Applications

\section{THEORY, CHARACTERIZATION AND MODELING}

TC1 In Silico Materials Chemistry

TC2 Design, Discovery and Understanding of Materials Guided by Theory, Computation and Data Mining

TC3 Materials Issues in Art and Archaeology

TC4 Advances in Spatial, Energy and Time Resolution in Electron Microscopy 


\section{MRS ENERGY @}

\section{SUSTAINABILITY}

\section{A Review Journal}

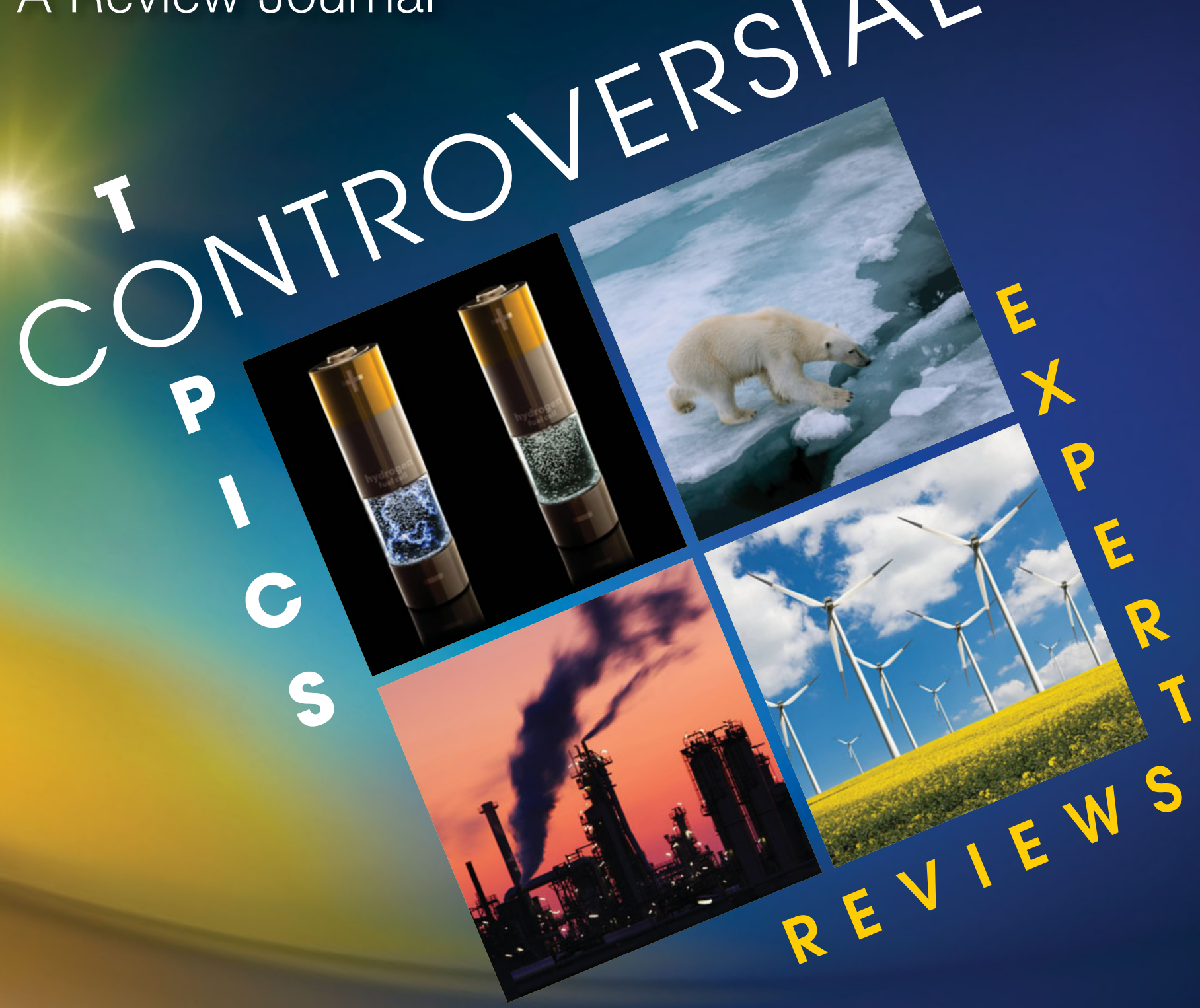

MRS Energy \& Sustainability-A Review Journal publishes reviews on key topics in materials research and development as they relate to energy and sustainability. Review topics include new R\&D of both established and new areas; systems integration; and objective application of economic, sociological and governmental models, enabling research and technological developments. The reviews are set in an integrated context of scientific, technological and sociological complexities relating to environment and sustainability.

\footnotetext{
는 David S. Ginley

퐁 National Renewable Energy Laboratory, USA

z David Cahen

के Weizmann Institute of Science, Israel

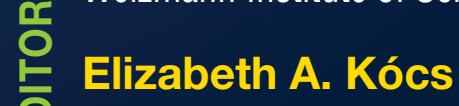

프 University of Illinois at Chicago, USA
} 